digérés et de nombreux becs. Dr. Johs. Schmidt vient de signaler ici même, dans l'estomac d'un dauphin capturé en Igro, au large de l'Espagne, en Méditerranee, la présence de I5.I9I otolithes de poissons que M. G. Allan Frost a pu attribuer (NATURE, Ier mars 1924, p. 310) aux genres Scombresox, Scopelus, Macrurus. Sir Sidney Harmer vient à son tour d'attirer l'attention sur la variété des constatations relatives à la nourriture des Delphinidés et la possibilité que les dauphins cherchent à l'occasion leurs proies sur le fond.

Je signalerai à ce propos les intéressantes observations de C. H. Townsend, sur des Tursiops truncatus capturés au Cap Hatteras et gardés en captivité à l'aquarium de New-York (Zoologica, juin I9I4). "The food of marine porpoises is chiefly fish and squid. . . . At Hatteras, they are known to feed largely on squeteague or weak-fish. The fact that sand has been found in the stomachs of porpoises, indicates that they sometimes feed at the bottom."

J'ajouterai que la présence d'Octopus dans l'estomac n'implique pas nécessairement que les dauphins vont jusqu'au fond chercher leur nourriture, les Octopus pouvant nager activement à certains moments et même en grand nombre. D'ailleurs, d'une manière plus générale, il y aurait lieu de reviser les notions que nous avons de l'habitat d'un grand nombre d'animaux du fond, puisque les pêches de nuit, à la lumière, que nous poursuivons depuis deux ans, M. L. Fage et moi, dans la zone littorale, nous ont révélé la nage très active de nombreuses espèces considérées comme sédentaires parmi les groupes zoologiques les plus variés.

La question de la nourriture des dauphins étant à nouveau posée par les diverses lettres publiées dans NATURE, je me propose de profiter des ressources particulières du port de Concarneau pour en faire l'objet d'une enquête étendue. R. LEGENDRE.

Laboratoire Maritime du Collège de France, Concarneau (Finistère).

\section{The Isotope Effect in Line and Band Spectra.}

IN two recent letters to NATURE (March 29, p. 459, and April 19, p. 567) Nagaoka, Sugiura, and Mishima, and again in another letter in NATURE of April I2, p. 532, Nagaoka and Sugiura have pointed out the existence of certain relations, which they ascribe to isotopy, between the positions of more or less widely separated spectral lines. The present writer is concerned with these communications mainly because they may cause confusion in regard to two letters of his own to NATURE (March 22, p. 423, and April 5, p. 489 ) on the isotope effect in band spectra.

Nagaoka and his associates have in effect assumed that the equations for the vibrational isotope effect in infra-red band spectra are applicable to line spectra in many cases. Their procedure is at variance with the present interpretation in terms of the quantum theory of the differences between line and band spectra. In the first letter they have assumed that a number of mercury and bismuth lines (all the mercury lines considered are well-known series lines) are due to a quasi-elastically bound nucleus-proton combination inside the planetary electron shells, but otherwise similar to a $\mathrm{HgH}$ or $\mathrm{BiH}$ molecule. In the second letter they have assumed diatomic molecules of various elements (lithium, neon, silicon, chlorine, argon, copper, zinc, bromine, and rubidium) to be responsible for the emission of a number of the spectral lines of these elements.

Out of a number of objections which might be raised to their assumptions, a few will be cited, as follows: (I) the observed spectroscopic frequencies of the different lines or groups of lines, the structure of which they explain in terms of isotopy, should, according to the same theory, consist of a fundamental and a series of approximately harmonic frequencies: actually, there are no such relations among the lines which they consider; (2) according to the quantum theory of band spectra, each vibrational frequency should be converted into a structured band due to the effect of molecular rotations (perhaps reduced to one or a few lines in the case of mercury and bismuth) ; (3) at least in the case of the emitters dealt with in the second letter, the observed frequencies are very much too high for the vibrations of diatomic molecules, as is shown by band spectrum data : all known molecular vibration frequencies, even for hydrogen compounds, correspond to infra-red radiation.

It seems altogether probable that such agreements as have been found with their "theory" by Nagaoka and his associates are accidental. Even the apparently excellent agreement with their formula in the case of the satellites of the mercury and bismuth lines fails, in the examples for which data are given, if one attempts to find corresponding satellites or groups of satellites, of correct relative intensity, for each isotope. Also, the assumption of six bismuth isotopes is not in harmony with positive ray analysis of other odd-numbered elements; in fact, only one isotope would be expected in view of the integral and odd atomic weight $(209 \cdot 0)$. The very accurate measurements of these writers on the satellites of mercury and bismuth lines should, however, be of much value.

The writer wishes to emphasise the fact that the very questionable theoretical foundations of the results of Nagaoka and his associates are not shared by the theory of the isotope effect in band spectra. The existence of the vibrational and rotational isotope effects in band spectra is a necessary conclusion from the quantum theory of band spectra, and is furthermore checked by experiment.

Jefferson Physical Laboratory,

Robert S. Mulliken.

Harvard University

Cambridge, Mass.

\section{The Effect of Naphthalene Vapour on Red Spider Mite (Tetranychus telarius, L.).}

AFTER a long series of experiments in attempting to control red spider in cucumber houses by fumigation, it has been found possible to utilise the vapours of naphthalene for the purpose. Red spider is the worst pest with which the grower of cucumbers has to contend, and the continuous attacks year after year have made the problem of control one of prime economic importance.

The irritating vapour evolved when naphthalene is quickly heated has an almost immediate anæsthetic action on the mite, but under such conditions the foliage of the cucumber plant is liable to severe injury. By suitable adjustment of the temperature at which solid naphthalene is maintained, it is possible to kill the spider without in any way harming the plant.

For fumigation purposes, it appears that the optimum temperature at which the naphthalene should be kept lies between $30^{\circ}$ and $46^{\circ}$ C., the spider becoming comatose during the first 16 hours and being definitely killed within $4^{8}$ hours under these conditions.

Use has been made of the hot-water pipes in cucumber houses for obtaining these temperatures, the naphthalene being first melted and smeared the

NO. 2849 , VOL. I I 3$]$ 